world. In this dynamic and sensitive situation any change in flooding will also alter the distribution and numbers of fish, inevitably affecting also the fisheating birds, while a change in vegetation could affect the seed-eating birds.

Man has chosen to dam this flood water and harness its energy to increase the hydroelectric output for expanding industrialisation. The outlook for the only population of semi-aquatic Kafue lechwe is bleak.

As we go to press we learn that the second dam has been completed but not finally closed. Already some changes in the flood regime have occurred.

\title{
The Vital Lechwe Lek
}

\author{
RichardH.Schuster
}

The author has studied the behaviour of the lechwe on the Kafue Flats, and shows how their remarkable breeding behaviour would be destroyed by changes in the flood regime of the Flats; this in turn could destroy this unique subspecies.

The dam at Itezhi-tezhi, because it will change the duration and extent of the annual floods, is expected to bring ecological changes to the Kafue Flats that could result in the disappearance of the Kafue lechwe. The writer's research on the social organisation and forms of social contact in Kafue lechwe (Schuster, in press) has revealed a complex set of behavioral and structural adaptation to the floodplain ecology. Any drastic change could disrupt the lechwe's social organisation and so interfere with breeding success and endanger its future.

During the main breeding season from about mid-November until the end of January, adult males occupy and defend small territories which are compressed together to form a territorial breeding ground known as a lek. This functions only as a mating ground. When a female is in oestrus, she enters the lek and selects the male who will court and mate with her. The social status of territorial occupants is very unequal. Unlike most other territorial antelopes, very few territorial lechwe breed. The majority of females gather around only one male who herds them tightly together into a harem within his small territory. Another unusual feature is that lek locations tend to be traditional, literally the same from year to year.

Lekking, known principally in a few species of birds, is a most unusual phenomenon. The Kafue lechwe is one of only two known species of territorial mammals that are known to breed on leks. The other is a relative of the lechwe, the Uganda kob, Kobus kob thomasi. Leks are also exciting to watch. The lechwe is a beautiful and majestic animal. When 200 rutting males are gathered in one small area competing for the one territory where females will go, lots of activity can be expected. What makes the show especially striking is the ritualised ceremonial of the social contacts between competing males and between courting males and females. Males rarely fight over territories, but confront each other with displays of tearing at the ground, head-high poses, and mock charges. Threat displays have evolved as instincts in order to avoid injuries from serious combat. Courtship, too, is ceremonial. Males prance, repeatedly lift their fore-legs to touch the female and mount before mating is achieved. These rituals seem to ensure that the female will select one male from 
the many and will remain within his small territory and be receptive to him.

The problem for the future is that the lechwe's complex instinctive rituals may function best within a lek social organisation. The majority of pregnancies occur during the 2-3 months when lekking occurs. If the ecological conditions on the Kafue Flats no longer support a lek system, the rate of reproduction might decline. One condition known to favour lekking is high population density. The Kafue Flats presently can support such a population because of the annual flooding, the herds grazing over a large area as they move in advance of the rising flood. The grass is fertilised with the droppings of lechwe, birds and fish, creating new lush grazing as the flood recedes. Any reduction in the flooded area and increase in flooding duration will force the lechwe to rely upon less grazing for longer periods, especially at the flood peak. The result will be smaller herds and less population pressure to maintain the lek organisation. Changes in flooding might also disrupt lekking by interfering with annual migrations through lekking areas. (Migrations would also be disrupted by planned irrigation channels.) Also, more new-born lambs might die. The favourite lambing places are tall grass surrounded by water where lambs lie hidden and immobile for many days. If these areas are denuded by overgrazing or made inaccessible by prolonged flooding, lambs will be exposed and easily killed.

Poaching is an additional danger. Lechwe may have survived until now because the high reproductive rate from lekking overcame the annual losses through poaching. But smaller herds with a lower reproductive potential would have little hope. The gregarious lechwe, gathered in herds of hundreds or thousands, give an impression of boundless numbers, and local hunters probably wonder what all the fuss is about. But the history books record numerous instances when vast herds were plundered to the point of extinction. The 70,000 remaining Kafue lechwe are hardly a large population.

These predictions are based upon a continuation of the present conditions and expected changes in the flooding cycle. The present research into social organisation can be applied in a concerted effort to save this unique and valuable animal which is capable of utilising a floodplain that for cattle is uninhabitable as well as for most other potential sources of protein. (1) Efforts could be made immediately to protect the few lek areas from poachers and other sources of interference, including commercial fishermen, tourists and cattle, if funds for protecting the entire region are unavailable. (2) Schemes to crop and transplant lechwe could be more than a 'numbers game'. It could now be possible to select animals and herds in ways which will interfere as little as possible with reproduction and provide a needed source of protein legally. (3) Plans to regulate the annual flooding cycle can be devised in such a way that ecological conditions required by the lechwe are maintained. (4) The FAO (1968) plan could be implemented to create a larger national park by combining Lochinvar, Blue Lagoon, and adjacent Game Management Areas. This would remove some of the present restrictions on lechwe migration and provide a larger area within which the animals could seek refuge.

\section{Notes}

1. Research was supported by funds from the Kafue Basin Research Project (KBRP) of the University of Zambia, the Fauna Preservation Society, and ZESCO who donated a Land Rover and funds for aerial photography to the KBRP.

2. Papers describing this research in more detail will be published in Science (international journal of The American Association for the Advancement of Science), Black Lechue, and a book of collected papers by researchers funded by the KBRP. 